\title{
Laparoscopic resection of a large hepatic cyst compressing the inferior vena cava
}

Rachel E Green, ${ }^{1}$ Simon Rajendran, ${ }^{2}$ Mohi Eldin Babiker, ${ }^{3}$ Hugo Prins ${ }^{3}$

${ }^{1}$ RCSI, Connolly Hospital, Dublin, Ireland

${ }^{2}$ Department of Surgery, Royal College of Surgeons, Dublin, Ireland

${ }^{3}$ Department of General Surgery, Connolly Hospital, Dublin, Ireland

\section{Correspondence to}

Dr Simon Rajendran,

simonrajendran@gmail.com

\section{DESCRIPTION}

A 67-year-old man presented with sudden onset shortness of breath that began while playing golf.

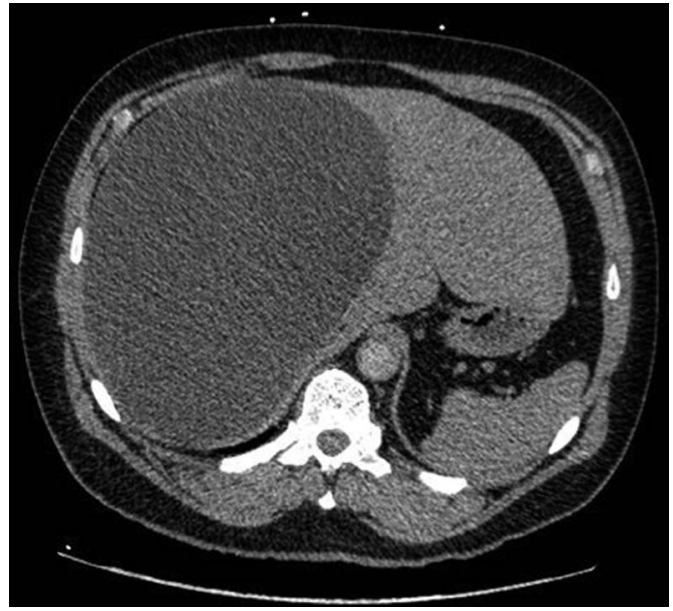

Figure 1 Axial section of abdominal CT reveals a large
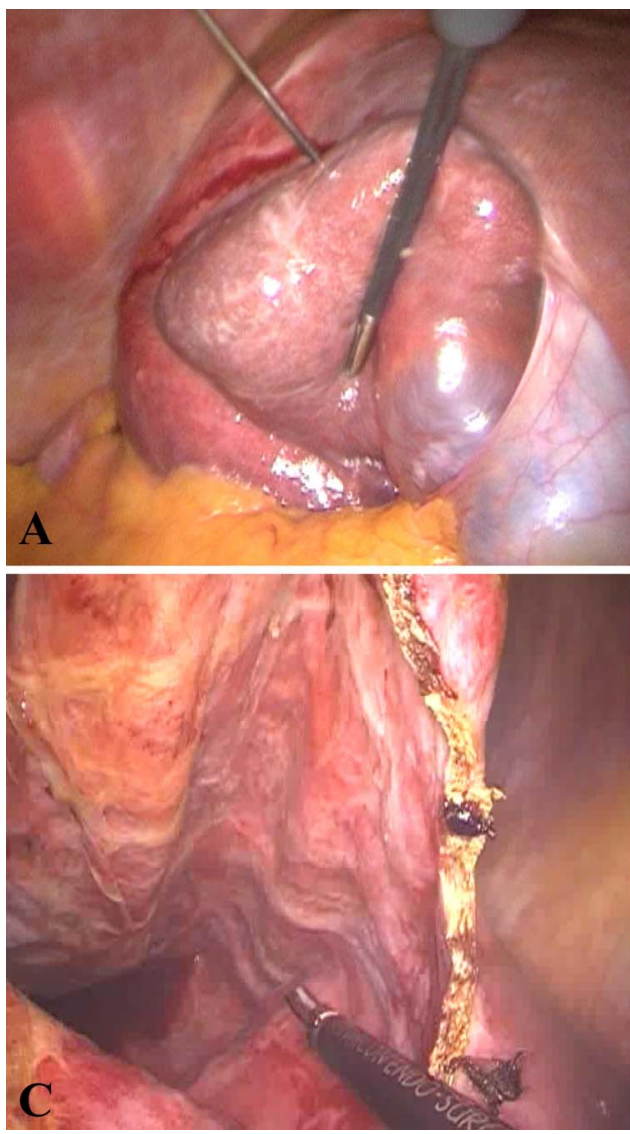

D

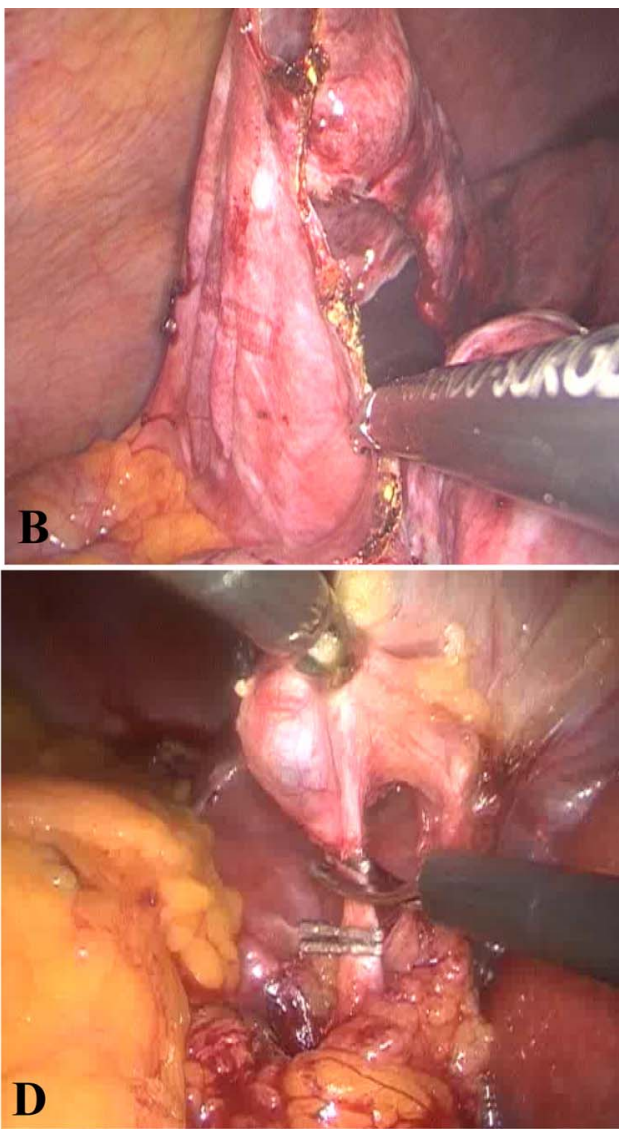

Figure 3 Intraoperative images demonstrating (A) large hepatic cyst on the right lobe of the liver, (B) excision of hepatic cyst laparoscopically, (C) inferior vena cava compression from large cyst with no evidence of thrombosis and (D) cholecystectomy.
Abdominal examination revealed a large mass extending to the umbilicus. CT pulmonary angiography demonstrated a pulmonary embolus and a

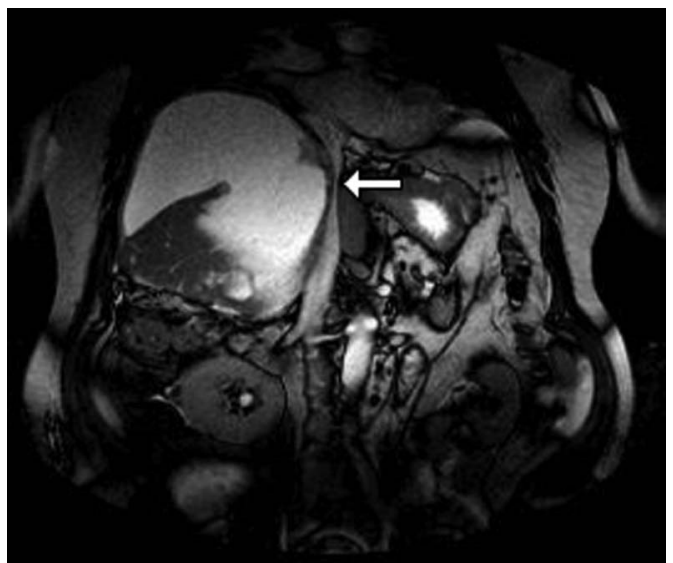

Figure 2 Coronal section of a T2-weighted MRI showing compression of the inferior vena cava by a large hepatic cyst.
Rajendran S, Babiker ME et al. BMJ Case Rep Published online: [please include Day Month Year doi:10.1136/bcr-2013009638 
large hepatic cyst (figure 1). MRI confirmed a $20 \mathrm{~cm}$ hepatic cyst in the right lobe compressing the inferior vena cava (IVC; figure 2). A smaller cyst $(5 \mathrm{~cm})$ and gallstones were also visualised. Hydatid serology and tumour markers (CA19-9 and $\alpha$-feto protein) were negative. The patient underwent an uncomplicated laparoscopic resection of the hepatic cyst and a cholecystectomy (figure 3). To prevent further pulmonary embolism, the patient was warfarinised prior to surgery and bridging anticoagulation with intravenous heparin was used to provide antithrombotic coverage preoperatively. Intermittent pneumatic compression and foot pumps were used intraoperatively and warfarin was reintroduced for 3 months after surgery. Final histology showed a cyst of epithelial origin.

The IVC maintains an intimate association with the liver. IVC compression leading to thrombus formation and pulmonary embolism is rare. ${ }^{1}$ Causes include hepatobiliary malignancy and benign causes such as large cysts. ${ }^{1}$ Liver cysts are classified as simple or complex. ${ }^{2}$ Investigations, including tumour markers, hydatid serology and multiple imaging modalities are essential in determining pathogenesis. Treatment is indicated in large or symptomatic cysts. ${ }^{3}$ Percutaneous drainage, laparoscopic marsupialisation and resection are all suitable techniques. This case highlights that large hepatic cysts can cause IVC compression leading to pulmonary embolism. Surgical resection is required to relieve compression, with laparoscopic techniques yielding good outcomes.

\section{Learning points}

- Large liver cysts can cause IVC compression predisposing to thrombus formation and pulmonary embolism.

- A thorough investigation by means of tumour markers, hydatid serology and multiple imaging modalites help determine etiology.

- Treatment options include percutaneous drainage, marsupialisation and resection which may be performed either by open or laparoscopic technique.

Contributors All authors have contributed to the management of the patient and drafting the manuscript. All authors have read and approved the final version of the manuscript.

Competing interests None.

Patient consent Obtained.

Provenance and peer review Not commissioned; externally peer reviewed.

\section{REFERENCES}

1 England RA, Wells $\mathrm{P}$, Gutteridge CM. Benign external compression of the inferio vena cava associated with thrombus formation. Br J Radiol 2005;78:553-7.

2 Vachha B, Sun MRM, Siewert B, et al. Cystic lesions of the liver. Am J Roentgenol 2011;196:W355-66.

3 Treckmann JW, Paul A, Sgourakis G, et al. Surgical treatment of nonparasitic cysts of the liver: open versus laparoscopic treatment. Am J Surg 2010;199:776-81.

Copyright 2013 BMJ Publishing Group. All rights reserved. For permission to reuse any of this content visit

http://group.bmj.com/group/rights-licensing/permissions.

BMJ Case Report Fellows may re-use this article for personal use and teaching without any further permission.

Become a Fellow of BMJ Case Reports today and you can:

- Submit as many cases as you like

- Enjoy fast sympathetic peer review and rapid publication of accepted articles

- Access all the published articles

- Re-use any of the published material for personal use and teaching without further permission

For information on Institutional Fellowships contact consortiasales@bmjgroup.com

Visit casereports.bmj.com for more articles like this and to become a Fellow 